\title{
Traversing Divides: My 'Integrated' Sister
}

\author{
Dan Cass
}

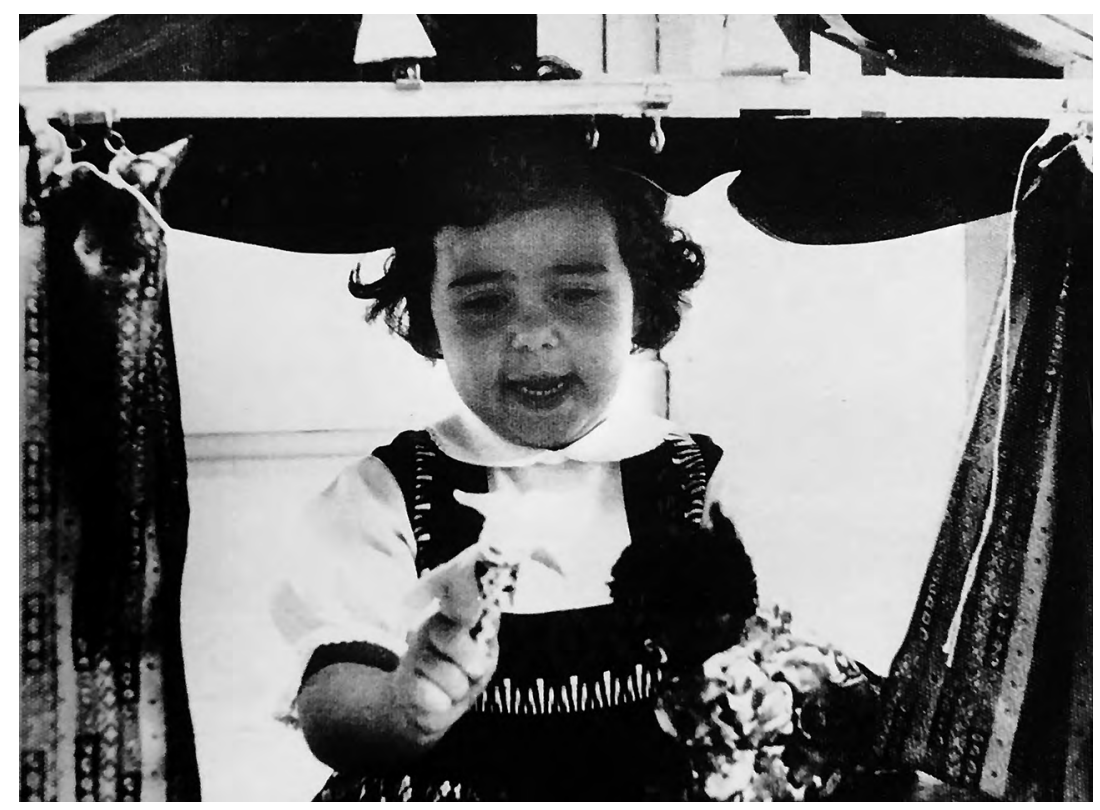

Deborah and her finger puppets, circa 1964.

Source: Photo provided by Dan Cass.

Deborah Cass was my sister and I want to share some of what I know about her. I think it is easy to connect her personal story with her scholarship or politics, because she was such a clear, integrated person. Everyone has contradictions; many people have commented to me that Deborah was so much herself: teaching law, cooking dinner, meditating while in intensive care, writing that book-with-the-long-title, mothering her daughters, listening to friends. 
I am not the only one who wishes Deborah was beside us. In her introduction to this volume, her dear friend and mentor Hilary Charlesworth writes, 'it is wonderful to have her writings as a continuing source of inspiration and consolation'. Hilary writes of 'Deborah's firm, clear voice, her appreciation of language, her seriousness, her curiosity, her sensitivity and her wry humour'.

If you had ever lost an argument with Deborah you would be surprised to know she was shy once. Our parents, Shirley and Moss, made her a theatre to help build her confidence. Dad constructed a wooden stage. Mum sewed a curtain on it and fashioned a troupe of finger puppets. The photo in this chapter shows Deborah, circa 1964, acting out a little play, literally trying on different characters, to find her own voice. Her ability to listen to the stories of the world and tell better ones is a clue to her power.

\section{Stories and Change}

Deborah reinvented herself many times in her life: hippie child of the 1960s, a stint in Melbourne's outer suburbs in the late 1970s, student politician at the University of Melbourne in the 1980s, rising scholar in the 1990s, aspiring author and thorough seeker of health and spiritual truth, from her cancer diagnosis in 2003 until her death in 2013.

Deborah's love of stories blossomed when she learned to read. I inherited some of her childhood favourites, paperback editions of The Chronicles of Narnia by CS Lewis and some of the Moomintroll series by Finnish artist and writer Tove Jansson. As a teenager Deborah read and reread the Greek myths and held them close to her through her life. When she spoke of one of the myths, her eyes brightened with wonder.

She built a strong story of self but never lost her tenderness. For as long as I can remember, she would sometimes grab my head in both hands and say, 'I used to change your nappies!', then shake her head, with a theatrical frown, 'How is that possible?' When she was in year seven she walked home from school at lunchtimes to see baby me. If I find life hard now, I imagine talking to her and I feel comforted.

1 See in this volume, Hilary Charlesworth, 'Traversing the Divides: Remembering Deborah Cass'. 
Deborah came of age in Melbourne and Canberra in the heady days of 1970s. At the end of the 1960s Deborah and our sister Naomi joined the world's oldest socialist-Zionist youth movement, Hashomer Hatzair, or Hushy. As in so many things, I followed them, a decade later. We all went on the camps with other children of left-wing Jews, sung Israeli songs and danced and debated peace in the Middle East and other political and even philosophical issues around the campfire. Hushy was the place I first heard about postmodernism, in about 1985, when one of our universityage leaders read us some of Italo Calvino's If on a Winters Night a Traveller.

I don't think I have ever experienced such a loving and ethical community as Hushy, and I know it was a big part of Deborah's life. Her daughter Rosa spent her own gap year in Israel, on a program with the progressive Zionist group, Netzer.

My parents sent Deborah and our oldest sister, Naomi - who she was very close to - to an experimental high school, Brinsley Road Community School, in Camberwell. Deborah soaked up the counterculture and she never became cynical about its aspirations for a peaceful, ecological, dare we say it, 'paradigm shift'. She made friendships that lasted her whole life, such as filmmakers Sharon Connolly and Trevor Graham. At the end of the second term of her final school year she dropped out.

Deborah grew her beautiful hair down to the waist. Deborah and Naomi ran barefoot around the sand dunes at Somers where our parents had a diminutive beach house, built from a shipping container. Deborah, or 'Dood' as we called her, loved the music of her time, from Pink Floyd's spaced-out Ummagumma, to those nice Jewish boys Simon \& Garfunkel.

She never forgave my parents for refusing to let her go to Sunbury Rock Festival, Australia's answer to Woodstock, when she was about 14. In more recent years she went to see Leonard Cohen multiple times and could be heard yelling over the stage barriers, 'I love you, Lennie!'

After Brinsley Road, Deborah reinvented herself around a conventional life. She left home and moved to Melbourne's outer eastern suburbs with a man who worked in TV. She taught herself to bake-including her famed pavlova and sachertorte - and sold cakes to a shop. They played doubles tennis and bet on horses. They had a personal computer and she drove a sports car with a sun roof. I was so proud! She read novels and learned to touch-type and supported herself working as a medical secretary. 
When she finally decided to change again, it was because of a conversation. A wise friend of the family told her that she didn't need a destination, rather a path. He told her that she should study, because learning is like a bus: you just get on and it takes you to new places.

When Deborah finally returned to do her final year of school, her ambition and her exam results steered her to law at the University of Melbourne. She never looked back. She graduated with honours, won five prizes including the scholarship that paid for her to do her Master of Laws (LLM) at Harvard University, and then topped it off with Harvard's prestigious legal doctorate, the Doctor of Juridical Science, or SJD.

Deborah threw herself into campus life, studying arts/law at the University of Melbourne. She lived in a share house on Rathdowne Street in North Carlton, and walked or cycled the dozen blocks to campus. She dyed her hair pink. One Monday morning I told my incredulous friends at the boys' school I went to that on the weekend I had been at my sister's party and saw two women passionately kissing each other.

Deborah was a successful political organiser. She came to university life as a very adult radical; a builder, not a smasher, articulate and confident. She helped form the Labour Club which displaced the ALP Club in elections to the student council. She won the role as editor of Farrago, the University of Melbourne student newspaper, with Tania Patston and James Button, two of her close, lifelong friends.

She took me to see Talking Heads. I followed her to a protest at a joint USAustralian military base in the northern Melbourne suburb of Watsonia where her comrades were all dressed as spies, in trench coats and dashing hats and silly glasses.

Deborah never did finish the arts degree, or make a career in politics, but both these sides of her are integral to understanding who she was. For her, the law was always a practical endeavour, to make the world better. She loved stories and was masterful at making them, and this talent gave her the resilience she needed later in life. 


\section{Law or Literature}

If the law was the great love of Deborah's hard-working intellect, then her first love was literature. She loved debating books, including with her friends who were successful authors.

After falling ill in 2003 Deborah retired from the law, to get healthy and care for her darling daughters. After her first operation, she took to writing fiction. This was a surreptitious enterprise at first, but later she spoke of it to friends and studied writing at RMIT (formerly the Royal Melbourne Institute of Technology). She had some short stories published and started on her novel.

When Deborah died, it was our mother who came up with the idea of commemorating her through a literary prize. By Shirley's design, the Deborah Cass Prize for Writing goes to early-career authors, who have a migrant background (a writer is eligible if they or one of their parents migrated to Australia). It is optimistic and a tribute to our grandparents, European Jews who migrated to Australia early last century, as a safe haven from anti-Semitism.

The Prize is also a tribute to her loving friendships. Her two coeditors from Farrago, James Button and Tania Patston, manage the judging and fundraising and with other friends and family, raised the funds to establish the Prize in 2015. Of the three esteemed, inaugural judges, two were close friends she made at uni: Christos Tsiolkas and Tony Ayers. (Alice Pung was the third inaugural judge, and like Tony and Christos, has drawn on the migrant experience in her work.)

A translator whose family migrated from Tuscany, Moreno Giovannoni, won the first Prize in 2015 and his beautiful book, The Fireflies of Autumn, was published in July 2018, by Black Inc.

The Prize is for literature, but in an era of resurgent nationalism, it has a broader impact, because literature is an antidote to bigotry. David Kidd and Emanuele Castano at the New School for Social Research have presented experimental evidence that literary fiction improves 'theory of mind'. The theory of mind is our brain's ability to detect the emotional 
states of others, understand these emotions and represent their intentions and beliefs in our own minds. It is a scientific model of what is generally known as empathy. ${ }^{2}$

Deborah had great empathy and knew the power of stories. For her, there had to be a point to an argument, even on an obscure topic. Deborah was driven to find the world meaningful and just.

\section{Slow Politics}

Deborah steered away from student politics and towards the law, and brought her values with her. She was patient and practical. She believed in intellectual achievement and was very proud of hers, but she was not a snob. She knew that change has to happen through democracy.

I think that her years in suburbia had a big impact on Deborah. In between Brinsley Road and her return study, she worked as a sales representative for JM Dent \& Sons. Dent published the Everyman Library of classics and Everyman Encyclopaedia, using modern printing press technologies to make books cheap enough to be read by a broad audience.

One of the great things about America, until relatively recently, was a respect for learning and a desire for rationality. ${ }^{3}$ Middle-class and working-class readers educated themselves. America had a multiplicity of middlebrow magazines that were fierce cheerleaders for nature, rationality, science and technology: National Geographic, Reader's Digest, Popular Science, Discovery, Popular Mechanics.

Even when Deborah moved to highbrow Harvard and then the London School of Economics, she expressed no disdain for her past in the suburbs. She knew that middlebrow readers are still intelligent readers who should be taken seriously; indeed, that our democracy depends on it. She loved mastering complexity but knew change comes from big ideas, expressed simply.

2 David Kidd and Emanuele Castano, 'Reading Literary Fiction Improves Theory of Mind' [2013] (342) Science 377, doi.org/10.1126/science.1239918.

3 See for example, Susan Jacoby, The Age of American Unreason in a Culture of Lies (Vintage Books, 2018). 
Deborah's big idea was 'trading democracy'. This meant that rather than trying to maximise the freeness of trade, or protesting for its fairness, we painstakingly build the institutions to enable its democratisation. Her big work in this area was The Constitutionalization of the World Trade Organization (CWTO), which was originally her SJD thesis at Harvard.

Deborah gave copies of her book to all her family, including our paternal grandfather, Ben Cass, who was 103 at the time. Papa was only just easing up on his long-held habit of reading The Economist every week, marking the important points in all the key articles and sometimes posting them to Deborah and his other grandchildren, according to their areas of professional interest. Deborah wasn't the first person in the family to see the highlighting pen as a civilisational triumph.

In Kerry Rittich's chapter on CWTO she writes that Deborah was 'always unhappy with intellectual ventures that stopped short of reform, "what is to be done" being very much part of her orientation both as a scholar and as a human being. ${ }^{4}$

Unfortunately, we know almost nothing about Deborah's vision for a synthesis of trade liberalisation and international economic democratisation. Rittich says that Deborah's book was a 'constitutional ground-clearing exercise'. 5 It mastered the field, schematising previous schools of thought but only teasing us with the merest outline of her alternative.

For those who want to explore the possibilities Deborah was uncovering, Rittich offers thoughts from an earlier essay that Deborah wrote, in which she looked at the debate between the accepted, or 'Mainstream', view in international law and the 'Newstream' critique. As Hilary Charlesworth also notes, Rittich says Deborah was critical of the conservativism of orthodoxy but also the inability of the rebels to effect real change.

I think this is a key point about her philosophy. She had the courage to make the radical critique but the modesty to know it had to make an impact on the world as it is.

4 See in this volume, Kerry Rittich, 'Deborah Cass, The Constitutionalization of the World Trade Organization: A Reading in Time' 15.

5 Ibid 16. 
Deborah's politics was always practical as well as intellectual. While she was at the University of Melbourne, a judge ruled that a sex worker who had been raped had suffered less because of her profession, so Deborah organised a protest and condemned the judgment on the evening TV news. Before she went back to study in the 1980s, Deborah won a considerable sum in the lottery and donated a significant amount to the African National Congress to support its struggle against apartheid in South Africa.

In our family we often discussed politics, sometimes a little too monotonously. Our father, Moss, had been a Cabinet Minister in a shortlived but energetically reforming left-wing Australian Government. ${ }^{6}$ Deborah had a rare confidence in the political process.

Deborah saw the law as deeply political and a vehicle for change. She agreed with Jenny Morgan, one of her closest friends and a colleague in the law, who writes that Deborah's work demonstrates that 'law cannot be read without politics, history and, I would say, feminism'. ${ }^{7}$

I admired Deborah's patience and rigour. I remember when she deferred from her studies to be a research assistant to counsel at the Nauru Commission of Inquiry into the Rehabilitation of Phosphate Lands in Nauru.

The tiny island of Nauru, in the western Pacific, had been covered with deposits of calcium phosphate, as pure and valuable as any in the world. This industrial-grade fertiliser was in the faeces of sea birds over at least 80,000 and perhaps as long as 300,000 years. ${ }^{8}$ While Nauru was administered by Australia, the phosphate was taken for Western industrial agriculture and was vital to the economic development of Australia and New Zealand.

Although Deborah had the commission's most junior legal role, she left a big mark. Tony Anghie recalls that she had the 'massive task of scouring the archives in various places including London, Geneva, New York, New Zealand, Melbourne and Fiji'. He writes:

6 Moss Cass, Vivien Encel and Anthony O'Donnell, Moss Cass and the Greening of the Australian Labor Party (Australian Scholarly Publishing, 2017).

7 See in this volume, Jenny Morgan, 'Introduction to "Constitutional Work".

8 SJ Gale, 'The Mined-out Phosphate Lands of Nauru, Equatorial Western Pacific' (2016) 63(3)

Australian Journal of Earth Sciences 334, doi.org/10.1080/08120099.2016.1206621. 
We relied completely on the several filing cabinets full of documents that Deborah had so carefully compiled and catalogued ... It is a testament to the thoroughness and precision of Deborah's work that the case that was later argued in the International Court of Justice was based on the foundations that she had laid ... Deborah had provided all that was needed.?

This diligence was a matter of her character. She wanted to change the world and knew, as Max Weber wrote, that '[p] olitics is a strong and slow boring of hard boards'. ${ }^{10}$

\section{The Healthy Self}

If politics is a struggle against chaos, then so too is having a body. Cancer brought chaos to Deborah's body and her family. She had multiple operations over a decade, in London and then at Melbourne's excellent Peter MacCallum Cancer Centre. I think that two of her important sources of strength during this period were her diligence and her storytelling.

When Deborah realised that the cancer was truly serious and ongoing, she moved her family back to Melbourne. I moved soon after from Sydney and so for several years our family of origin lived in the same city. The closeness forged with Deborah over those years and the experience of getting to really know Gerry, Hannah and Rosa is a highlight of my life.

Deborah responded to mortality and suffering with courage and focus. She became an expert, bringing a notebook to all her medical meetings. She worked hard at being as healthy as possible. She redirected her brilliant mind from the law to the big philosophical questions about life and death. Again, she reinvented herself, telling herself the story that would open up new horizons.

She truly did defy the odds. At one meeting with her team in 2012 they said Deborah was doing so well that she was, statistically speaking, 'off the graph'. She had survived years longer than any of the surgeons or oncologists had predicted. Even then, in her last year, they were optimistic about what she could achieve, in her remarkable way.

9 See in this volume, Tony Anghie, 'Self-Determination and Beyond: Reflections on the Aftermath of the Nauru Case'.

10 Scott Horton, 'Weber on the Political Vocation', Harper's Magazine (Web Page, 8 June 2008) $<$ https://harpers.org/blog/2008/06/weber-on-the-political-vocation/>. 
Every day she was able, Deborah went for a long walk. She made her own fresh juices. She bought a vast range of healthy foods and supplements. She read about Buddhism, meditation, spirituality, cognitive science, conventional medicine and alternative therapies. She continued to enjoy poetry, novels, and the papers, including the London Review of Books and Melbourne's Age.

At one point in the latter years, Deborah was readmitted to hospital. I was the one spending time by her bed that week. (Naomi, our sister, often slept in the hospital room and tended to Deborah there and when she was at home, with incredible dedication.) On this particular occasion I entered Deborah's hospital room to find her bed empty.

After gathering courage, I went to the nurses' station to ask what had happened. There was silence until a young nurse said Deborah had raised her weak and pained body and was walking around the ward, leaning on the infusion pump. The nurse said, 'she's like the Terminator'.

Like many people, I had always avoided thinking about death, before Deborah fell ill. A good friend recommended I read Elisabeth KüblerRoss (1926-2004), the Swiss-American psychologist who founded the clinical study of how Western people face mortality. On Death and Dying, published in 1969 (Simon \& Schuster), proposes that we are unable to really comprehend our own death. She observed we try to 'bargain' with fate. We think that if we are morally worthy, then God will heal us. Or, for the atheists, we think that if we work hard (at meditation or positive thinking or consuming healthy foods and supplements), then our bodies will heal us.

In her last couple of years, I used to go around every second weekend to help her make a vast volume of freshly squeezed vegetable and fruit juice, which she believed was holding the cancer at bay. These were lovely times, when we would talk for hours about everything under the sun. We often went for a coffee - a dandelion brew for her - to Me \& Julio, the café on her street in North Fitzroy, opposite the school yard. One day she suddenly faced me and said, 'It's not fair that I am going to die and you are going to still be here'. We cried and I held her tight. 
Gerry and their girls were amazingly strong through these years. Gerry supported Deborah and her choices, even when her path took her to realms they could not share. The girls and Gerry gave all their love to her. Their home was a happy one, full of all the normal joys and dramas that come with two children growing up.

Over that last difficult and amazing decade, Deborah worked hard to tell the best story she could about herself, the cancer and the meaning of her life. I think that the creativity of the storyteller in her sustained her life for so many years longer than the doctors gave her. In her early life she fell in love with stories and the power they have to remake us. She never gave up on that little Deborah inside.

She studied Buddhism and practiced meditation, at times for several hours a day. She went on retreats. When she died in 2013, Sogyal Rinpoche sent an email to followers around the world asking them to meditate for her.

Deborah also turned to Judaism. She found a teacher to instruct her in the foundations of the Kabbalah and spoke of it with close friends like Kim Rubenstein in Canberra and Jon Turner QC in London.

This part of her journey was an unusual one for our family. Our parents had brought us up as atheists, or at least rationalist and agnostic. As children we went to the synagogue together for the big days in the religious calendar: Rosh Hashana (New Year) and Yom Kippur (the Day of Atonement). This was more for connection to a shared culture and history than connection to God.

The one body of the Jewish canon which we all could recite was the comedy. Shirley, our mum, has a particularly wicked sense of the absurd. During times of difficulty - or indeed any time - she would lob a grenade of bitter-sweet pathos and blow up any solemnity. I can see Deborah holding her sides, crying with laughter.

We loved the films of the Marx Brothers and Woody Allen, and the family record and cassette collections included Tom Lehrer and Lenny Bruce.

The family favourite was the 1965 classic, 'You Don't Have to Be Jewish'. One sketch we all loved was the supposed reading of the will of a Samuel B Cohen, of Long Island, New York. 
The sketch consists of Cohen's executor reciting the will, to squeals of admiration and sotto voce commentary. There is one million dollars to ' $m y$ beautiful boy Sheldon' and the same amount to 'my beautiful daughter', 'who has been a little too particular or she'd be married already'. Cohen's wife gets two million and 'the Picasso from the back of the store'. To his brother-in-law Louis, 'who lived with us all his life' and 'who never had to do a day's work' and 'always smoked the best cigars; mine' and 'who all his life said I'd never remember him in my will; hello Louis!'

I loved walking and talking with Deborah. Wherever she lived in that big last decade, she took long walks, swinging her arms vigorously and holding herself erect. She was convinced that this gave vitality to her immune system. She experienced the clarity it brought to her mind. In Melbourne and at her Somers beach house she brought along trusty Angus, her little Scottish Highland Terrier.

I shared Deborah's fascination with neuroscience. We loved Norman Doige's bestseller, The Brain that Changes Itself(Penguin, 2007), and I gave her Daniel J Siegel's Mindsight (Random House, 2010). The promise of this new generation of neuroscientists is the idea that we can use our thoughts to change our brains.

This appealed very much to Deborah's sense that we can use the power of the stories we tell to shape ourselves and our societies, as moral agents. Neuroplasticity provides a scientific approach to practice of meditation and an empirical account of its positive impacts. If we can use the software of our thoughts to repeatedly think in more mentally healthy ways, then our brain will, over time, rewire into more mentally healthy hardware.

Daniel Siegel is a clinical neuroscientist who has expanded this vision of neuroplasticity into the social realm. He theorises that wellbeing is a function of three factors: brain, mind and relationships. If our relationships carry some of the content of our mind, then they influence our brains.

On our walks together, Deborah discussed her hope that a unified theory of brain and self was emerging. She enjoyed thinking that science and spirituality could find a deep connection through concepts of mind.

Deborah did not need to read neuroscience to know how to love and be loved. Even when sick, she was often busy with friendships: writing aerograms, making cakes, talking through problems. She used to advise, 'I water my friends better than you do'. 
Deborah wanted to know everything. She also wanted to be in the thrall of becoming, of mystery. I love the story of her playing with finger puppets on her little stage as a girl, but her strength was a mysterious force, rising from her unconscious.

On 25 June 2014, Natalia Schiffrin, Philippe Sands QC and other of Deborah's London friends put on a beautiful memorial for her at Burgh House, near Hampstead Heath. Maria Aristodemou spoke rather intensely about the exhilarating and sometimes confronting sense of being in the moment with Deborah.

Maria said that Deborah had something she wanted for herself: an honesty that was fundamental. Deborah was, in psychoanalytic terms, the 'Ego' that Maria wanted to become, 'the ethical subject for whom there's no distance between the "saying" and "the said" ... [who can] speak their desire without fear and without lying. ${ }^{11}$

As you might hope, I think there is a valuable political lesson for us in Deborah's personal struggle. The biggest challenge facing the world is global warming and it is something that I have worked on, and cried about, since 1991. When people ask me, 'is there any hope left?', I now reply that it is not the most useful question.

After doing my part to help Deborah struggle for health, I learned that hope is not the point. Her struggle made our lives bigger, because we lived it fully with her. She may have hoped for a cure and bargained for the impossible, but she got up each day and lived meaningfully.

We live in a real world of objectively knowable truths, but we relate to them through the stories we tell and the courage we have to face things as they are.

I recall Deborah's friendships, mindfulness, singing to Leonard Cohen, long walks with Angus the terrier, afternoons listening to radio broadcasts of summer test cricket, weekends at her Somers beach haven, fearless and tender cultivation of her daughters and love of her husband, and they all remind me how to live well. She knew her story would have the ending she did not want, but she kept telling better stories about herself and the world, each day.

11 Email from Maria Aristodemou to Dan Cass, 31 January 2017. 
This text is taken from Traversing the Divide: Honouring Deborah Cass's Contributions to Public and International Law, edited by Kim Rubenstein, published 2021 by ANU Press, The Australian National University,

Canberra, Australia.

doi.org/10.22459/TD.2021.08 